\title{
EOGENETIC CAVES IN PLEISTOCENE CARBONATE CONGLOMERATE IN SLOVENIA
}

\section{EOGENETSKE JAME V PLEISTOCENSKEM KARBONATTEM KONGLOMERATU V SLOVENIJI}

Mateja Ferk, Matej Lipar



Canyon in conglomerate; the Sava River is cutting its way through the conglomerate of Sorško Polje.

Kanjon v konglomeratu; Sava si je vrezala strugo v konglomerat Sorškega polja. 


\section{Eogenetic caves in Pleistocene carbonate conglomerate in Slovenia}

DOI: $10.3986 /$ AGS52101

UDC: $911.2: 551.44(497.4)$

COBISS: 1.01

ABSTRACT: This paper focuses on caves in Pleistocene carbonate conglomerates in Slovenia and for the first time defines them as eogenetic. The conglomerates show no deep burial that would resemble the mezogenetic stage of diagenesis and are still in the phase of early diagenesis (i.e. eogenetic stage). Based on speleological analysis the eogenetic caves were grouped into four types; (1) linear stream caves, (2) shelter caves, (3) breakdown caves, and (4) vadose shafts. All four types of caves, described in this paper, can appear individually, however, complex cave systems are often a combination of passages of different types.

KEY WORDS: geography, karst geomorphology, speleology, caves in conglomerate, eogenetic caves, Pleistocene, Slovenia

The article was submitted for publication on December 7, 2011.

\section{ADDRESSES:}

Mateja Ferk

Anton Melik Geographical Institute

Scientific Research Centre of the Slovenian Academy of Sciences and Arts

Gosposka ulica 13, SI - 1000 Ljubljana, Slovenia

Email: mateja.ferk@zrc-sazu.si

\section{Matej Lipar}

Environmental Geoscience

Department of Agricultural Sciences

Faculty of Science, Technology and Engineering

La Trobe University,

Victoria 3086, Australia.

Email: mlipar@students.latrobe.edu.au

\section{Contents}

1 Introduction 9

2 Caves in conglomerate 9

3 Pleistocene conglomerates in Slovenia 9

4 Eogenetic caves 10

5 Eogenetic caves in Pleistocene

6 Discussion 20

7 Conclusion 21

8 Acknowledgements 22

9 References 22 


\section{Introduction}

Caves in conglomerate have already been recognised and described in Slovenia (Gantar 1955; Žlebnik 1978; Gabrovšek 2005; Kranjc 2005; Lipar and Ferk 2011) as well as worldwide (Günay 1985; Bergadá et al. 1997; Filippov 2004; Ferrarese and Sauro 2005; Zampieri et al. 2005; Lapaire et al. 2006; Goeppert et al. 2011). However, they still remain one of the less researched features in the karst literature. Furthermore, in Slovenia, detailed studies of caves in conglomerate have only been focused on caves in the Udin Boršt conglomerate terrace (Gantar 1955; Gabrovšek 2005; Kranjc 2005; Lipar and Ferk 2011).

Even though caves in conglomerate are often categorised as one type of caves, numerous different cave types can be identified within this group. The genesis and morphology of caves are strongly influenced by conglomerate characteristics which makes geological predispositions important for understanding of speleogenesis in conglomerates. In Slovenia, the cave types in Pleistocene conglomerate for example are much different when compared to cave types in Tertiary or older conglomerates. During diagenesis, conglomerates can be modified by different processes (e.g. covered by marine sedimentation of limestones, clays) and their characteristics can become more similar to telogenetic limestones than to younger conglomerates in eogenetic stage; for example, the speleogenesis of caves in Oligocene conglomerates in Slovenia (e.g. Marijino Brezno Cave (Reg. No. 6)) is more similar to cave formation in limestones of Mesozoic age (Kataster jam JZS 2011). Consequently it is crucial to draw a precise line between conglomerates in different diagenetic stages.

This paper discusses the main characteristics of speleogenesis of caves in conglomerates in eogenetic geological stage of diagenesis and is therefore focused on caves in Pleistocene conglomerate. Based on the wide range literature review and field work, this paper summarizes detailed speleological analyses of all known caves in Pleistocene conglomerate in Slovenia. The main objectives are (1) to represent the distribution of Slovenian caves in Pleistocene conglomerate, (2) to describe their morphology and speleogenesis, and to (3) introduce general types of eogenetic caves in conglomerate.

\section{Caves in conglomerate}

The term »caves in conglomerate « resembles broad geological (sedimentological) point of view and refers to caves, which have formed in a coarse-grain $(>2 \mathrm{~mm})$ cemented sediment, also known as calcirudite. However, due to different age of conglomerate, its different grain mineralogy, porosity, and even metamorphosis, the variety of cave types in conglomerates is high. The term is very broad and usually further characterization is needed to interpret caves more in detail.

Caves in eogenetic conglomerate of Miocene or Pleistocene age have been reported from Italy (Ferrarese and Sauro 2005; Zampieri et al. 2005), Turkey (Günay 1985; Değirmenci and Günay 1993) and Slovenia (Gantar 1955; Gabrovšek 2005; Kranjc 2005; Lipar and Ferk 2011). Generally, the majority of those caves have been influenced by the matrix porosity of conglomerate, its permeability, and neotectonics. Hence many similarities are present when comparing those caves.

On the other hand, caves of older conglomerate have been reported from Russia (Ordovician age) (Filoppov 2004; Klimchouk 2004), Switzerland (Oligocene) (Lapaire et al. 2006), Spain (Eocene, Oligocene) (Bergadá et al. 1997; Ortega 2000), China (Cretaceous) (Lynch 2003a and 2003b; Zhang 2011), Austria and Germany (Oligocene, Miocene) (Goeppert et al. 2011), and Slovenia (Oligocene) (Planina 1954 in 1955; Kataster jam JZS 2011). Although the greater age of the rock does not necessarily exclude the eogenetic stage, many of those caves are still different from the caves in Pleistocene conglomerate due to different characteristics of the conglomerates. Cautious and careful examination of conglomerate is needed before comparing or typifying all the caves in conglomerate together.

\section{Pleistocene Conglomerates in Slovenia}

Conglomerates in Slovenia were deposited through several periods of geological history (the oldest are of Devonian age) (Markič 2009; Novak and Skaberne 2009; Pavšič and Horvat 2009; Ramovš and Buser 2009; Skaberne et al. 2009). The older conglomerates including those of Tertiary age went through different phas- 
es of diagenesis and are no longer in the eogenetic stage (i.e. are in the mezogenetic or telogenetic stage). The younger conglomerates of Quaternary age show no deep burial that would resemble the mezogenetic stage of diagenesis. Therefore, they are still in eogenetic stage.

In the Quaternary (Pleistocene) contrasted climatic alternations came into force with typical changes between the glacial and interglacial periods. Pleistocene sediments in Slovenia are genetically related, at least indirectly, to the activity of glaciers that covered a large part of the Alps during their largest extent (Melik 1930; Šifrer 1952, Kuščer 1955; Šifrer 1961, Meze 1966; Šifrer 1969 and 1992; Bavec and Verbič 2004), and covered also the highest parts of the Dinaric Mountains (Snežnik, Trnovski Gozd) (Osnovna geološka karta SFRJ 1972; Bavec and Pohar 2009) while periglacial phenomena were characteristic for the Pohorje Mountains (Natek 2007; Gams 2008). Remains of glacial sediments are mainly limited to higher mountainous regions. The sedimentation of fluvioglacial and fluvial sediments has taken place along the river systems. Accumulations of Pleistocene sediments are typical for the Ljubljana Basin, along the middle and lower Sava River, Soča River (Komac and Zorn 2007; Komac 2009), along the entire Savinja River, along the rivers Drava and Mura, and specifically also on karst poljes of the Dinaric Karst region (Stepišnik and Mihevc 2008; Bavec and Pohar 2009; Stepišnik et al. 2012). Except Drava and Mura, the rivers are carrying mostly carbonate gravel. The cement in carbonate conglomerates is mostly calcite. The fundamental work for the subdivision of Quaternary sedimentary fill in Slovenia (based on the key study from Ljubljana Basin) was done by Kuščer (1955). Later, Žlebnik (1971) divided the Quaternary fill into four units: the Older, Middle and Younger conglomeratic fills, and the latest gravel fill. In carbonate conglomerates karst features have formed (e.g. caves) and according to the geological development stage of the conglomerate we can interpret them as eogenetic karst features.

\section{Eogenetic caves}

The term »eogenetic « was introduced by Choquette and Pray (1970) and refers to »the time interval between final deposition and burial of the newly deposited sediment or rock below the depth of significant influence by processes that either operate from the surface or depend for their effectiveness on proximity to the surface (Choquette and Pray 1970, 219). It overlaps with the term »early diagenesis«, defined by Berner (1980).

Associated with »eogenetic stage«, two other terms were introduced for the time of deeper burial as "mezogenetic stage«, and the time related to erosion of long-buried carbonates as "telogenetic stage« (Choquette and Pray 1970, p. 219).

The term was later used in combination with the term karst as »eogenetic karst « (Vacher and Mylroie 2002; Florea and Vacher 2006; Grimes 2006; Ginés and Ginés 2007) as well as with caves as »eogenetic caves« (Vacher and Mylroie 2002; Grimes 2006; Smart et al. 2006; Florea et al. 2007; Ginés and Ginés 2007; De Waele et al. 2009). Generally, eogenetic caves form in soft, porous and poorly-consolidated limestones during their eogenetic stage of diagenesis (Grimes 2006), which partly limits them to the coastal regions (Vacher and Mylroie 2002; Grimes 2006; Smart et al. 2006; Ginés and Ginés 2007). Nevertheless, they have also been described inland (Florea et al. 2007; Lipar and Ferk 2011). Although often used for coastal caves in Quaternary limestones, the term »eogenetic caves« has only a general geological point of view and the variety of different types of caves is therefore great. Amongst the numerous different types of eogenetic caves, summarised by Lipar and Ferk (2011), eogenetic caves in conglomerate (based on caves of Udin Boršt, Slovenia) are represented by four general types.

\section{Eogenetic caves in Pleistocene conglomerate in Slovenia}

According to Slovenian Cave Register there are at least 36 registered caves in Pleistocene conglomerate in Slovenia (Kataster jam IZRK 2011; Kataster jam JZS 2011) (Fig. 1). However, the exact number is not possible to determine due to the newly found caves which are in registration process and some inaccessible and/or destroyed caves.

In Ljubljana basin, which is the only part in Slovenia with registered eogenetic caves in conglomerate, caves are mostly distributed on the edges of conglomerate terraces and river valleys. About $40 \%$ of 





caves are found in the Pleistocene terrace of Udin Boršt, while the others are found mostly on terraces and canyon cliffs of the Sava and Kokra Rivers (Fig. 1).

Table 1: Basic information of eogenetic caves in Pleistocene carbonate conglomerates in Slovenia.

\begin{tabular}{|c|c|c|c|c|c|c|}
\hline $\begin{array}{l}\text { registration } \\
\text { number }\end{array}$ & name & $\begin{array}{l}\text { lenght } \\
\text { (m) }\end{array}$ & $\begin{array}{l}\text { depth } \\
\text { (m) }\end{array}$ & $\begin{array}{c}\text { entrance } \\
\text { altitude (m) }\end{array}$ & $\begin{array}{l}\text { cadastral } \\
\text { commune }\end{array}$ & type* \\
\hline 367 & Jama pri Taboru & 110 & 7 & 460 & Cešnjica pri Kropi & linear stream cave \\
\hline 397 & Jama pri Lipniški Skali & 31 & 6 & 465 & Dobrava pri Kropi & shelter cave \\
\hline 763 & Arneževa Luknja & 815 & 13 & 470 & Duplje & linear stream cave \\
\hline 764 & Dopulnik & 306 & 6 & 466 & Duplje & linear stream cave \\
\hline 765 & Velika Lebinca & 200 & 13 & 421 & Strahinj & linear stream cave \\
\hline 766 & Mala Lebinca & 6 & 1 & 440 & Strahinj & shelter cave \\
\hline 1075 & Dacarjevo Brezno & 307 & 19 & 590 & Duplje & linear stream cave \\
\hline 1076 & Brezno v Kvikšovem Partu & 3 & 3 & 520 & Duplje & vadose shaft \\
\hline 1077 & Jama v Arhovem Partu & 13 & 5 & 520 & Duplje & vadose shaft \\
\hline 1078 & Arhova Jama & 25 & 3 & 465 & Duplje & linear stream cave \\
\hline 1081 & Arneševa Zijalka & 19 & 4 & 460 & Duplje & linear stream cave \\
\hline 1233 & Jama pri Dobravi & $?$ & $?$ & 420 & Zaloše & not determined \\
\hline 1315 & Jama pod Stolcem nad Zalošami & 11 & 2 & 450 & Zaloše & shelter cave \\
\hline 1339 & Šmajdov Grad & 8 & 3 & 390 & Predoslje & shelter cave \\
\hline 1340 & Urhov Kevder & 8 & 0 & 350 & Jama & shelter cave \\
\hline 1341 & Janharjeva Jama & 5 & 0 & 334 & Podreca & shelter cave \\
\hline 2404 & Ciganska Jama & 10 & 2 & 445 & Podbrezje & shelter cave \\
\hline 2746 & Projev Grez & 9 & 8 & 361 & Godešic & vadose shaft \\
\hline 2878 & Partizanska Jama pod Okroglim & 15 & 3 & 430 & Okroglo & shelter cave \\
\hline 3074 & Jama na Studencu & 10 & 0 & 274 & Slape & shelter cave \\
\hline 4171 & Kadunčev Studenec & 20 & 6 & 440 & Strahinje & linear stream cave \\
\hline 4172 & Kamponov Kevder & 10 & 0 & 340 & Breg ob Savi & shelter cave \\
\hline 4381 & Arhova Zijalka & 10 & 1 & 470 & Duplje & shelter cave \\
\hline 4580 & Spodmol 1 pod Dragočajno & 8 & 0 & 337 & Moše & shelter cave \\
\hline 4581 & Spodmol 2 pod Dragočajno & 6 & 3 & 337 & Moše & shelter cave \\
\hline 4582 & Spodmol 3 pod Dragočajno & 8 & 0 & 341 & Moše & linear stream cave \\
\hline 4583 & Turška Jama & 20 & 1 & 342 & Podreca & shelter cave \\
\hline 4599 & Pekel v Klemenčevem Gradišču & 17 & 6 & 462 & Gorice & linear stream cave \\
\hline 4639 & P-2 (Brezovica) & 21 & 9 & 480 & Cešnjica pri Kropi & linear stream cave \\
\hline 4648 & Vočanarjeva Luknja & 19 & 5 & 407 & Predoslje & not determined \\
\hline 4694 & Rokovnjača & 10 & 1 & 485 & Duplje & linear stream cave \\
\hline 6950 & Kačja Jama nad Spodnjimi Dupljami & 13 & 6 & 470 & Duplje & breakdown cave \\
\hline 8442 & Jama pod Žalami & 65 & 3 & 390 & Kamnik & linear stream cave \\
\hline 9874 & Konglomeratovka & 14 & 3 & 493 & Hraše & shelter cave \\
\hline 10025 & Vojvodov Kevder & 10 & 2 & 472 & Gorice & linear stream cave \\
\hline \multicolumn{7}{|l|}{ (in process } \\
\hline of registration) & Kinderjajček & 25 & 3 & 445 & Strahinj & linear stream cave \\
\hline
\end{tabular}

*listed is the prevailing type of cave passage genesis

The longest cave in Pleistocene conglomerate in Slovenia is Velika Lebinca Cave (Reg. No. 765) which is located in Udin Boršt and has 1154 metres of measured passages. It is followed by Arneževa Luknja Cave (Reg. No. 763) with 815 metres of measured passages, also situated in Udin Boršt. Excluding Udin Boršt with the largest concentration of eogenetic caves, the longest cave with 110 metres of measured passages is Jama pri Taboru Cave (Reg. No. 367) situated near the settlement Rovte in the vicinity of Podnart.

As it was determined by Lipar and Ferk (2011) for eogenetic caves in Udin Boršt, also the caves in Pleistocene conglomerate in Slovenia could be grouped into four different types of eogenetic caves: (1) linear stream caves, (2) shelter caves, (3) breakdown caves, and (4) vadose shafts.

The majority of caves can be determined as linear stream caves (Fig. 2, 3 and 8). They all function as permanent or ephemeral springs. No cave of this type has been noticed to be a ponor. Entrances are usually larger (i.e. higher than $1 \mathrm{~m}$ and a few metres wide; usually a shelter type entrance) than the horizontal cave passages, which become narrower upstream with distance from the entrance. Horizontal passages 


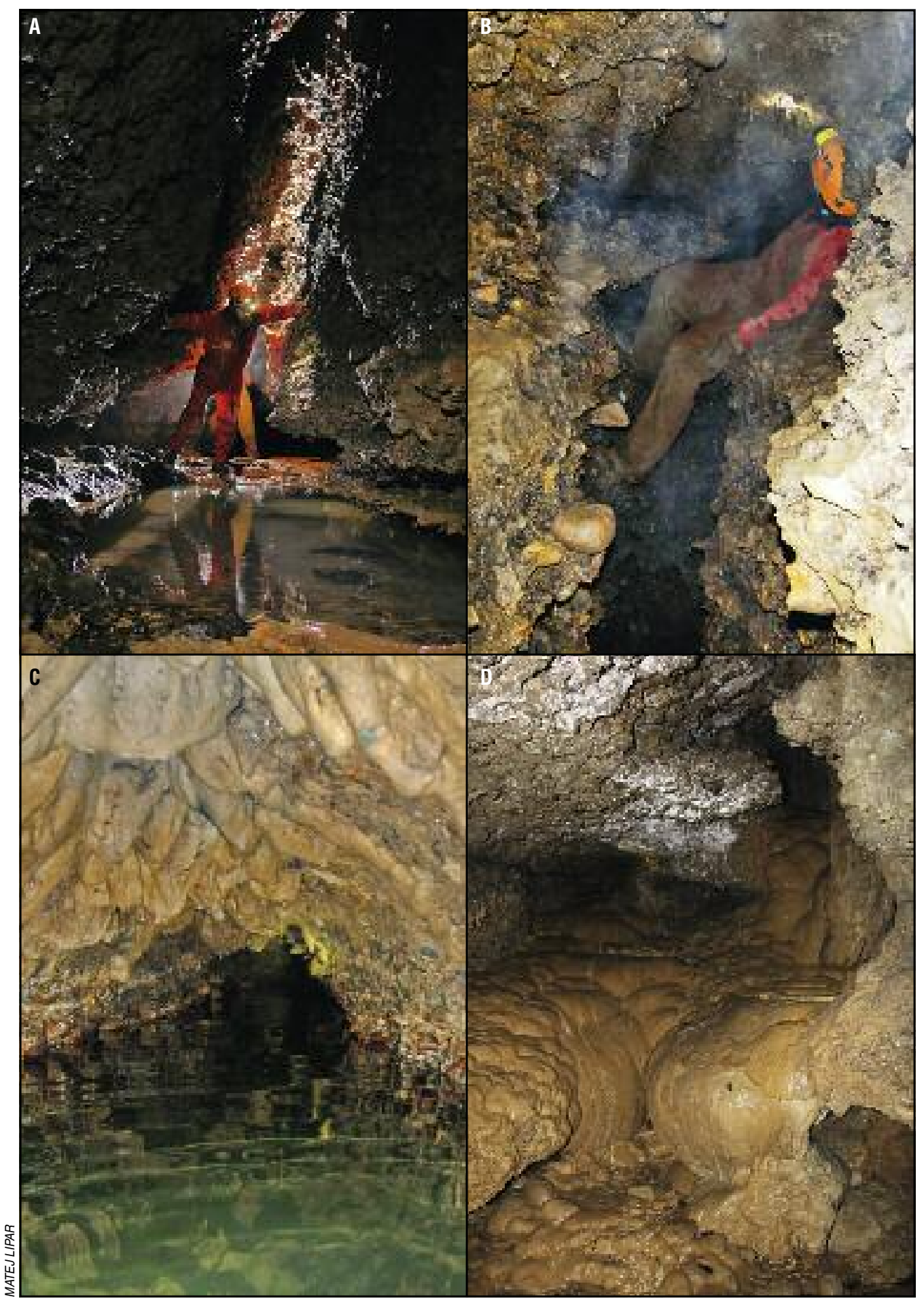

Figure 2: Examples of linear stream cave passages (A, B - Arneževa Luknja Cave; C - Dopulnek Cave; D - Kinderjajček Cave). 


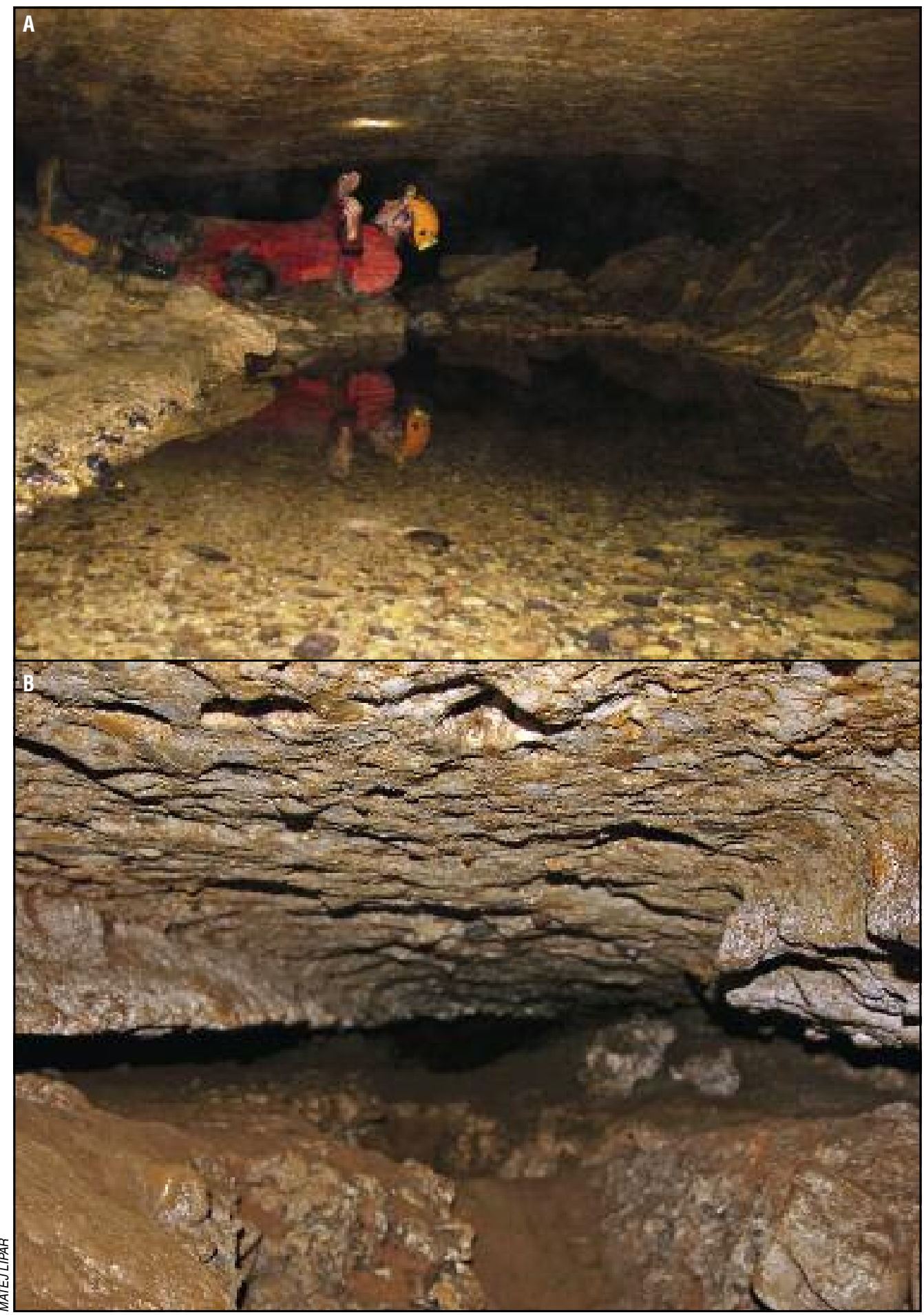

Figure 3: Passages influenced by matrix porosity (A - Arneževa Luknja Cave; B - Jama pri Taboru Cave). 
primarily developed at the piezometric level. The piezometric level changed in the past and consequently there are hydrological inactive passages in higher levels of some caves (e.g. in Arneževa Luknja Cave (Reg. No. 763), Jama pri Taboru Cave (Reg. No. 367)). Furthermore, due to the water level drop, in some caves the active water flow disappeared completely and some caves of the linear stream cave type are hydrologically inactive in present hydrological conditions (e.g. Spodmol 3 pod Dragočajno (Reg. No. 4582)). Usually, caves consist of a horizontal passage with a main stream and short side passages as tributaries to the main water flow. Speleogenesis of main stream passages is mostly controlled by fissure/joint porosity, described also by Bergadá et al. (1997), Lapaire et al. (2006) and Değirmenci and Günay (1993). Secondarily cross-fractures triggered and influenced the development of usually short side passages. The influence of fissure/joint control is indicated by relatively high and narrowing ceilings with generally visible fissures; and stalactites, which follow the main fissure (as in Dopulnek Cave (Reg. No. 764)) or side cracks (as in Arneževa Luknja Cave (Reg. No. 763)) (Fig. 2).

Nevertheless, in some sections passages are low and wide (as in Jama pri Taboru Cave (Reg. No. 367)), which reflect matrix porosity and bedding material type influence (Fig. 3). These passages do not have any visible fractures and stalactites are therefore scattered randomly on the cave roof. However, when comparing the cross sections of matrix-porosity-influenced passages, they are in general narrower when the conglomerate beds consist of bigger (between 1 and $10 \mathrm{~cm}$ ) pebbles; and wider when the beds are fine-grained (less than $1 \mathrm{~cm}$ big pebbles and sand grains). The fine-grained conglomerate is less resistant to erosion than the conglomerate of bigger pebbles. Similar passages have been described by Zampieri et al. (2005). However, certain parts of cave passages have been enlarged also due to collapses (as in Arneževa Luknja Cave (Reg. No. 763)).

Beside linear stream caves, there are numerous caves in Pleistocene conglomerate which resemble shelter caves (Fig. 4, 5 and 6). They usually form on the edge walls of terraces (e.g. Arhova Zijalka Cave (Reg. No. 4381)) or side walls of valleys or canyons (e.g. Spodmol 1 pod Dragočajno Cave (Reg. No. 4580)). In contrast to their rather simple morphology, their formation is a result of various factors. Ford and Williams (2007) consider shelter caves as a result of frost shattering; therefore termed also frost pockets. They usually appear on stronger carbonate rocks where there are wetted fractures via solutionally enlarged openings. However, solution is the trigger process for large scale frost weathering around the point of groundwater emergence (Ford and Williams 2007; cf. Zorn 2009).

Shelter caves in Pleistocene conglomerate are the a result of spring sapping by diffusely-fed streams through intergranular pores with no visible passages in the conglomerate as well as the result of frost weathering on different erosion resistant conglomerate layers, which both play a great role on the later evolution of the caves. Frost weathering is indicated also by broken fragments that are found on the shelter floors and range in sizes from sand to boulder-size rocks. If a »shelter cave « continues into a horizontal passage, the cave is interpreted as linear stream cave with shelter-type entrance (e.g. Jama pri Lipnici Cave (Reg. No. 397)). The size of entrances varies from 1 meter to more than 10 meter in wideness as well as from half a metre to more than 6 metres in height. Shelter caves usually extend about 10 meters into the conglomerate or less, and their width is sometimes greater than their length (e.g. Spodmol 2 pod Dragočajno Cave (Reg. No. 4581)) (Fig. 6).

As the registration of certain caves in Pleistocene conglomerate predates the modern Slovenian standard of minimum cave length $(10 \mathrm{~m})$, some registered shelter caves are shorter than $10 \mathrm{~m}$ (e.g. Janharjeva Jama Cave (Reg. No. 1341)). Herewith it should also be noted, that many unregistered shelter caves in Pleistocene conglomerate exist which are shorter than $10 \mathrm{~m}$. Shelter caves are usually completely dry and hydrologically inactive. However, in some cases they are still functioning as springs. But usually the water emerges a few metres below the shelter, and most of the streams are not active in periods of no rain. Where there are no initial voids to collect surrounding water into a strong flow, a number of small streams develops and hence multiple shelter caves may occur at the same (old or recent) piezometric level close to each other. The piezometric level is affected by the overall hydrological aspects and/or the boundary level between permeable conglomerate and non-permeable rock beneath it (i.e. Oligocene clay). Fissures are scarce and usually resemble only young fissures that appear at the edges of terraces or valleys due to unconformability of the conglomerate walls. Flowstone formations are usually absent. However, the primary morphology of many shelter caves is often anthropogenically reshaped as in the past a lot of them were used by people as shelters (e.g. completely reworked and walled up Šmajdov Grad Cave (Reg. No. 1339); Turška Jama Cave (Reg. No. 4583), which was reworked as a shelter for nearby villagers against Turks in $16^{\text {th }}$ century; Urhov Kevder Cave (Reg. No. 1340), which was serving as a storage place; Arhova Zijalka Cave (Reg. No. 4381), which was restored into a shed) (Fig. 5). 


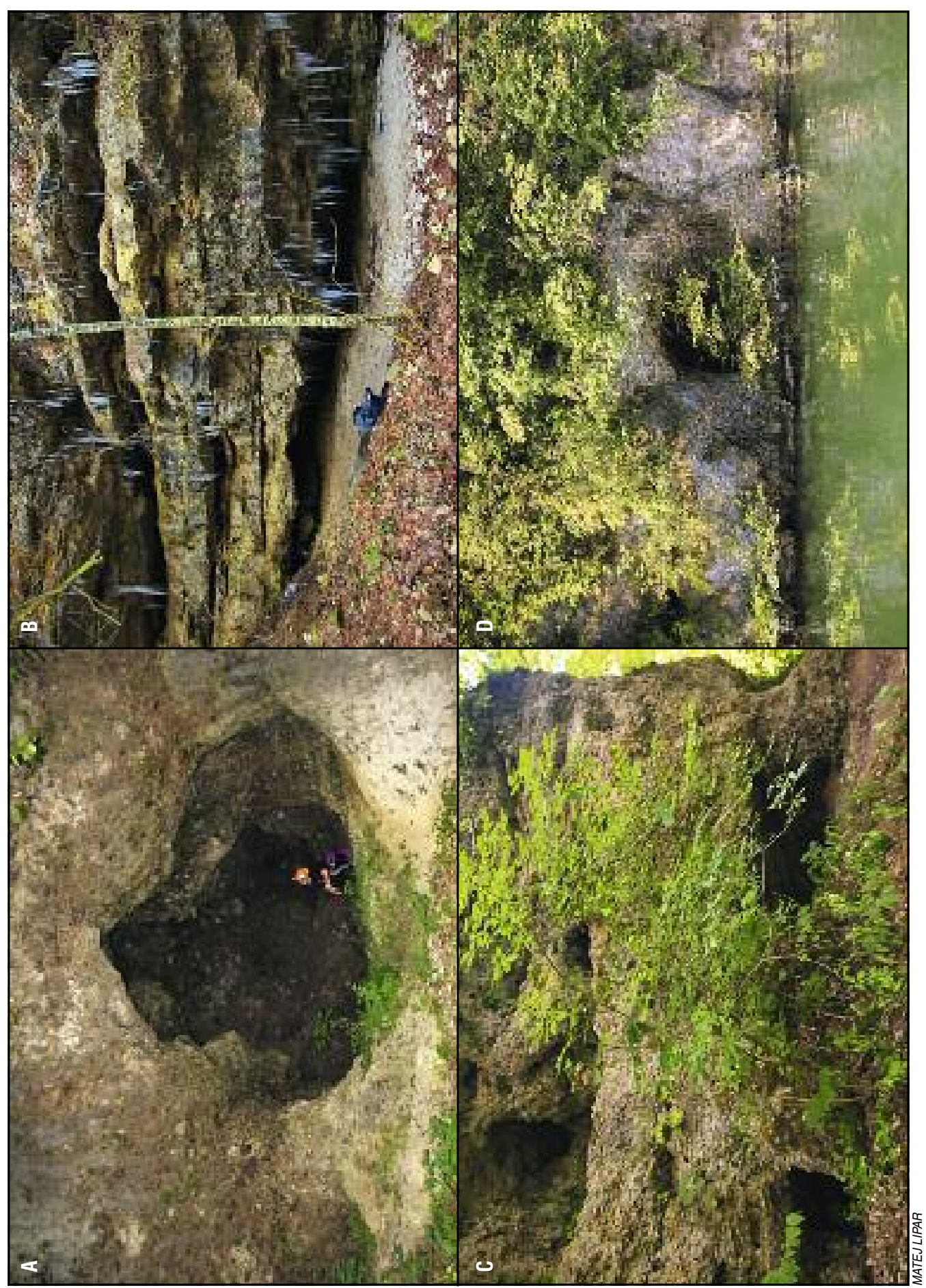

Figure 4: Examples of shelter caves ( $\mathrm{A}$ - Ciganska Jama Cave; B - small shelters in the Kokra River Canyon; C - Spodmol 1 pod Dragočajno Cave; D - Urhov Kevder Cave). 




Figure 5: Anthropogenically reshaped shelter caves (A - Turška Jama Cave; B - Šmajdov Grad Cave; C - Partizanska Jama pod Okroglim Cave; D - Dacarjevo Brezno Cave). 




Figure 6: Map of Spodmol 2 pod Dragočajno Cave.

Caves in Pleistocene conglomerate, which have been reshaped by collapses and the primary solutional passages are not present any more, are identified as the breakdown cave type (Fig. 7B and C). The collapses occur over pre-existing solutional passages due to crushed joint zone or instability of the weakly cemented rock in enlarged chambers. Collapsed passages are in a higher level than primary passages; therefore active water flow in breakdown caves is absent. However, breakdown caves may not be formed entirely of collapsed passages, since in some cases the primary epiphreatic passages can still be reached (e.g. in Kadunčev Studenec Cave (Reg. No. 4171)) (Fig. 8). In this case the »breakdown cave type « is rather omitted. Limited sections of local collapses in caves of a different type are not an appropriate indicator for the breakdown cave type. The basic difference between local collapses and a breakdown cave type is that the local collapse is a secondary process in a cave of a different type where the rocks, which were broken down from the ceiling, have not yet been removed (e.g. by flowing water) and represent an anomaly in a cave with prevailing other characteristics. On the other hand, the collapses and rockfall in the breakdown type of caves are a significant and dominant process of cave formation which completely reshapes the previous cave passages and forms »new « cavities on higher elevations above original stream passage.

Vadose shafts (Fig. 9), as a fourth type of caves in Pleistocene conglomerate, are rare and usually too short to represent a cave, which would be in accordance with Slovenian standard of minimum cave length. Caves, which fit in this category, have mostly been found in the Udin Boršt terrace. Furthermore, except the entrance part of Kačja Jama nad Spodnjimi Dupljami Cave (Reg. No. 6950), which is a vadose shaft, other caves with vertical entrances have been anthropogenically destroyed by filling of entrances with waste and other materials (e.g. Dacarjevo Brezno Cave (Reg. No. 1075); Jama v Arhovem Partu Cave (Reg. No. 1077); Projev Grez Cave (Reg. No. 2746); Jama pri Dobravi Cave (Reg. No. 1233)). However, smaller vadose shafts, though not big enough to be registered as caves (less than $10 \mathrm{~m}$ deep), have been found within the inner parts of the Udin Boršt conglomerate terrace. Vadose shafts can be simple shafts with no prospect for continuation on one hand, or the entrance parts of other cave types on the other. In the latter case, the genesis of vertical shafts and underlying horizontal passages are not necessarily related. Namely, they were formed in the vadose zone by focused seeping precipitation and this differs from morphogenetic processes which formed other types of caves described above.

A special cave in Pleistocene conglomerate in Slovenia is Vočanarjeva Luknja Cave (Reg. No. 4648) (Fig. 7A). It is a passage between collapsed blocks which used to be the edge wall in the valley, but have 


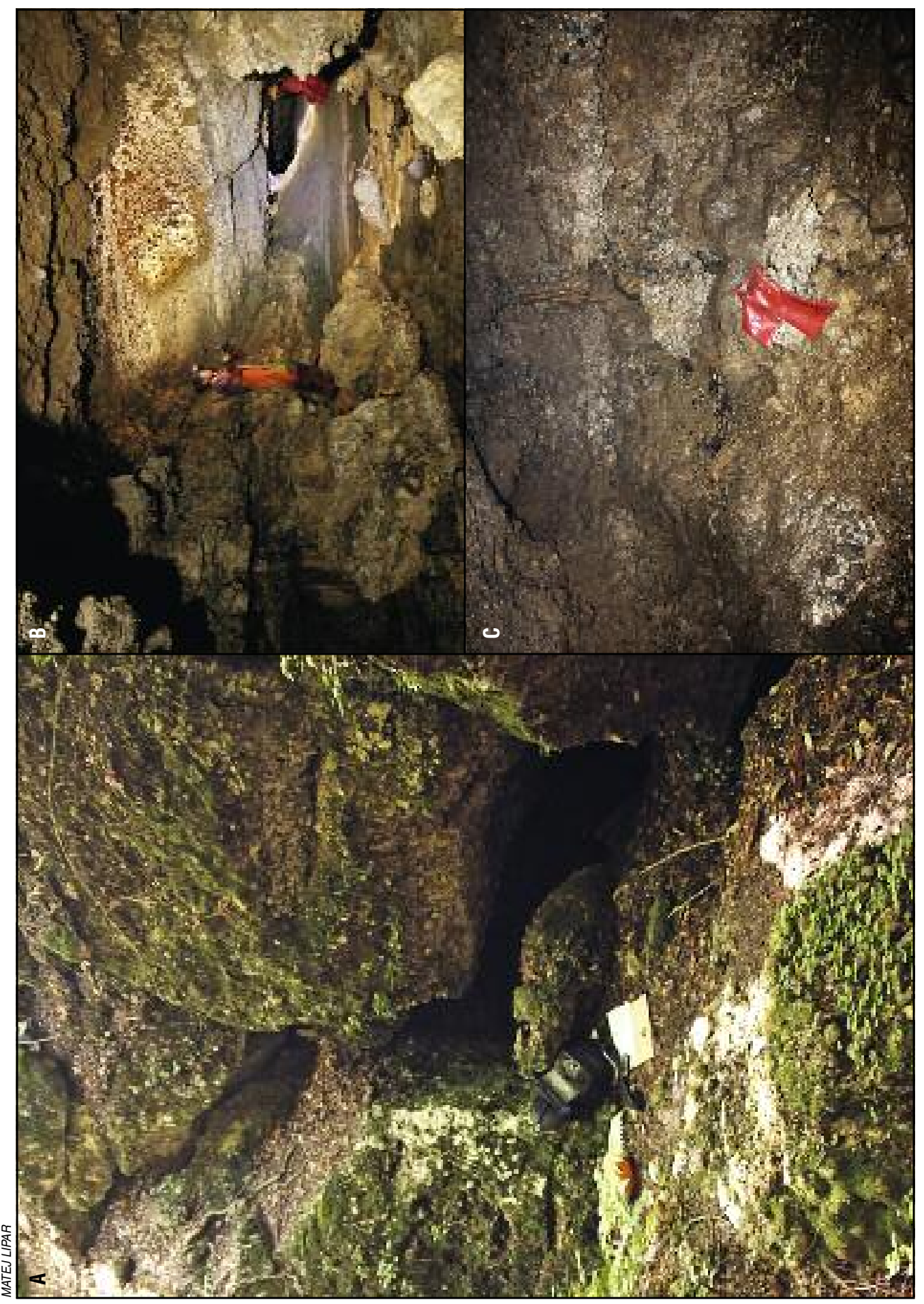

Figure 7: Examples of collapses (A - Vočanarjeva Luknja Cave; B - Arneževa Luknja Cave; C - Kačja Jama nad Spodnjimi Dupljami Cave). 




Author of contents/avtor vsebine: Tomazin Jože

Author of map/avtor načrta: Matej Lipar

Source/vir: Cave Register of SAS, 2011/ Kataster jam JZS, 2011



\section{LEGEND/LEGENDA:}

○. Loose pebbles/nesprijeti prodniki

$\therefore$ Fine grained sediment (sand)/drobnozrnat sediment (pesek)

$\diamond$ Collapsed blocks/podorni bloki

- Water flow direction/smer vodnega toka

- Water flow/vodni tok

-- Water flow under the cave passage/ vodni tok pod jamskim rovom

Figure 8: Map of Kadunčev Studenec Cave.

been separated from it by a collapse. As its formation is rather random consequence of cliff-edge erosion, it cannot be interpreted as any of the described types of caves in Pleistocene conglomerate nor as a new (special) type of eogenetic caves.

\section{Discussion}

Four types of eogenetic caves in conglomerate of Pleistocene age are described in this paper. Although the term "eogenetic « has a broad meaning and from certain aspects of geology may not be precise, we still refer to it as many papers have been published on eogenetic caves recently (Smart et al. 2006; Florea et al. 2007; Ginés and Ginés 2007; De Waele et al. 2009; Lipar and Ferk 2011). Furthermore, when referring to eogenetic caves, there is a common characteristic of rock, which partly influences overall genesis of caves: primary matrix porosity ("primary porosity « by Choquette and Pray (1970); "matrix porosity" by Ford and Williams (2007); »interparticle and vuggy « porosity by Lucia (2007)). Later during early diagenesis but still in eogenetic stage, primary porosity may experience modifications such as reduced permeability, but the type of porosity still remains the same. Nevertheless, new additional porosity (»secondary porosity« by Ford and Williams (2007)) may occur as well (e.g. fissure or conduit porosity).

In the Pleistocene carbonate conglomerate in Slovenia primary matrix porosity is still present. Pleistocene conglomerates are more or less cemented and also karstified, so the primary porosity is modified in different degrees. The matrix porosity is mostly expressed within shelter caves by seeping water through conglomerate matrix as well as in certain sections of linear stream caves, where low and wide passages were formed. Nevertheless, secondary porosity (i.e. fissure and crack porosity) occurs in Pleistocene conglomerates and affected certain cave formations as well. This could be seen in most of the linear stream caves, with main passages formed and oriented along the main joints. According to Ford and Williams (2007), dissolutional conduits (e.g. caves) resemble tertiary porosity, which in all determines Pleistocene carbonate conglomerate in Slovenia and consequently caves, formed in it, as a mixture product of primary, secondary, and tertiary porosity.

Caves in conglomerates in eogenetic stage should be distinguished from caves in conglomerates in mezogenetic or telogenetic stage (Filippov 2004; Klimchouk 2004; Goeppert et al. 2011), and from caves in other types of rocks in eogenetic stage (Jennings 1968; Grimes 2006; De Waele et al. 2009). 




Figure 9: Examples of vadose shafts (A, B - less than $10 \mathrm{~m}$ deep shafts in Udin Boršt; C - Kačja Jama nad Spodnjimi Dupljami Cave; D - Arneževa Luknja Cave).

\section{Conclusion}

Gravel material was deposited and later cemented to form conglomerates throughout the geological history of the Slovenian territory. Except the youngest conglomerate of Quaternary age, they went through several phases of diagenesis (e.g. burial or uplift-related diagenesis) and are therefore no longer in the eogenetic stage (i.e. they are in the mezogenetic or telogenetic stage). The biggest amounts of Pleistocene conglomerates are in the Ljubljana Basin in the central part of Slovenia and along some big river systems (Sava, Soča, Savinja, Drava and Mura). These conglomerates never went through a phase of deep burial during their diagenesis and are therefore still in the eogenetic stage. In the carbonate conglomerates, consisting mostly of limestone and dolomite pebbles, caves and surface karst forms have developed. These are the only parts in Slovenia where eogenetic karst forms have formed and therefore they could be interpreted as valuable geomorphological features or geomorphosites (Erhartič 2010).

In this paper eogenetic caves in Pleistocene carbonate conglomerates are analysed in detail. Based on extended speleological (morphological and morphometrical) analyses four types of eogenetic caves in 
Pleistocene conglomerate in Slovenia were described: (1) linear stream caves, (2) shelter caves, (3) breakdown caves, and (4) vadose shafts.

Linear stream caves were formed in the epiphreatic zone. They are mostly influenced by cracks and fissures (fissure porosity) and the type of the bedding material (matrix porosity). Shelter caves were also formed right above the epiphreatic zone and functioned or are still functioning as springs. The speleogenesis was strongly influenced by the matrix porosity and frost weathering. In some caves or cave passages the prevailing modification processes are collapses due to physical instability and such caves were determined as the breakdown type of caves. Like in other karst types (e.g. limestones and other rocks in the telogenetic stage), vadose shafts were formed where concentrated water flow seeped underground through the vadose zone. They were interpreted as the fourth type of eogenetic caves in Pleistocene conglomerates and can appear just as vertical openings, or they can present an access to caves of a different type of genesis (e.g. linear stream caves, breakdown caves). To conclude with, it is evident that all four types of eogenetic caves can appear individually, although it is common that large cave systems are a combination of passages of different types (e.g. Arneževa Luknja Cave (Reg. No. 763), Kačja Jama nad Spodnjimi Dupljami Cave (Reg. No. 6959)).

\section{Acknowledgement}

We wish to thank John A. Webb and Blaž Komac for comments on the early draft of the text. We also wish to thank two anonymous peer reviewers. The research was carried out whilst the author Matej Lipar was supported by a La Trobe University Postgraduate Research Scholarship in Melbourne, Australia.

\section{References}

Berner, R. A. 1980: Early Diagenesis, A Theoretical Approach. New Jersey.

Bavec, M., Pohar, V. 2009: Kvartar. Geologija Slovenije. Ljubljana.

Bavec, M., Verbič, T. 2004: The extent of Quaternary glaciations in Slovenia. Quaternary glaciations: extent and chronology. Developments in Quaternary science 1. Amsterdam.

Bergadá, M. M., Cervelló, J. M., Serrat, D. 1997: Karst in conglomerates in Catalonia (Spain): Morphological forms and sedimentary dequence types recorded on archaeological sites. Quaternaire 8, 2-3. DOI: 10.3406/quate.1997.1579

Choquette, P. W., Pray, L. C. 1970: Geologic nomenclature and classification of porosity in sedimentary carbonates. The American Association of Petroleum Geologists Bulletin 54-2. Tulsa.

De Waele, J., Mucedda, M., Montanaro, L. 2009: Morphology and origin of coastal karst landforms in Miocene and Quaternary carbonate rocks along the central-western coast of Sardinia (Italy). Geomorphology 106. DOI: $10.1016 /$ j.geomorph.2008.09.017

Değirmenci, M., Günay, G. 1993: Origin and catchment area of the Olukköprü karst springs. Hydrogeological Processes in Karst Terranes. IAHS 207. Oxfordshire.

Erhartič, B. 2010: Geomorphosite assessment. Acta geographica Slovenica 50-2. Ljubljana. DOI: 10.3986/AGS50206

Ferrarese, F., Sauro, U. 2005: The Montello Hill; The »classical karst« of the conglomerate rocks. Acta Carsologica 34-2. Ljubljana.

Filippov, A. 2004: Siberia, Russia. In: Gunn, J. (Ed.): Encyclopaedia of caves and karst science. New York, London.

Florea, L. J., Vacher, H.L. 2006: Springflow hydrographs: eogenetic vs. telogenetic karst. Ground Water 44-3. DOI: $10.1111 / j .1745-6584.2005 .00158 . x$

Florea, L. J., Vacher, H. L., Donahue, B., Naar, D. 2007: Quaternary cave levels in peninsular Florida. Quaternary Science Reviews 26. DOI: 10.1016/j.quascirev.2007.02.011

Ford, D., Williams, P. 2007: Karst Hydrogeology and Geomorphology. Chichester.

Gabrovšek, F. 2005: Jame v konglomeratu: primer Udin Boršta, Slovenija (Caves in conglomerate: case of Udin Boršt, Slovenia). Acta Carsologica 34-2. Ljubljana.

Gams, I. 2008: Geomorphology of the Pohorje mountains. Acta geographica Slovenica 48-2. Ljubljana. DOI: 10.3986/AGS48201 
Gantar, A. 1955: Arnešova luknja. Acta Carsologica 1. Ljubljana.

Ginés, A., Ginés, J. 2007: Eogenetic karst, glacioeustatic cave pools and anchialine environments on Mallorca Island: a discussion of coastal speleogenesis. International Journal of Speleology 36-2.

Goeppert, N., Goldscheider, N., Scholz, H. 2011: Karst geomorphology of carbonatic conglomerates in the Folded Molasse zone of the Northern Alps (Austria, Germany). Geomorphology 130. Amsterdam. DOI: 10.1016/j.geomorph.2011.04.011

Grimes, K. G. 2006: Syngenetic karst in Australia: a review. Helictite 39-2. Sydney.

Günay, G. 1985: Karst groundwater studies in Manavgat river basin, Turkey. Karst Water Resources (Proceedings of the Ankara - Antalya Symposium). IAHS 161. Oxfordshire.

Jennings, J. N. 1968: Syngenetic karst in Australia. Contributions to the Study of Karst. Department of Geography Publication 5. Canberra.

Kataster jam IZRK 2011: Inštitut za raziskovanje krasa Znanstvenoraziskovalnega centra Slovenske akademije znanosti in umetnosti. Postojna.

Kataster jam Jamarske zveze Slovenije, 2011: Jamarska zveza Slovenije. Ljubljana.

Klimchouk, A. 2004: Russia and Ukraine. Encyclopaedia of caves and karst science. New York.

Komac, B. 2009: Social Memory and Geographical Memory of Natural Disasters. Acta geographica Slovenica 49-1. Ljubljana. DOI: 10.3986/AGS49107

Komac, B., Zorn, M. 2007: Pobočni procesi in človek. Geografija Slovenije 15. Ljubljana.

Kranjc, A. 2005: Konglomeratni kras v Sloveniji: zgodovina raziskovanja in poznavanja jam v Udin Borštu na Gorenjskem. Acta Carsologica 34-2. Ljubljana.

Kuščer, D. 1955: Prispevek h glacialni geologiji Radovljiške kotline. Geologija 3. Ljubljana.

Lapaire, F., Becker, D., Christe, R., Luetscher, M. 2006: Karst phenomena with gas emanations in Early Oligocene conglomerates: risks within a highway context (Jura, Switzerland). Bulletin of Engineering Geology and the Environment 66-2. DOI: 10.1007/S10064-006-0068-8

Lipar, M., Ferk, M. 2011: Eogenetic caves in conglomerate: an example from Udin Boršt, Slovenia. International Journal of Speleology 40-1. Tampa. DOI: 10.5038/1827-806X.40.1.7

Lucia, F. J. 2007: Carbonate reservoir characterization: an integrated approach. Berlin, Heidelberg.

Lynch, E. 2003a: Deepest underground drop: new longest cave. Descent 172. Abergavenny.

Lynch, E. 2003b: Caving in conglomerate. Descent 174. Abergavenny.

Markič, M. 2009: Pliocen in pliokvartar. Geologija Slovenije. Ljubljana.

Melik, A. 1930: Bohinjski ledenik. Geografski vestnik 5-6. Ljubljana.

Meze, D. 1966: Gornja Savinjska dolina: nova dognanja o geomorfološkem razvoju pokrajine. Dela SAZU 20. Ljubljana.

Natek, K. 2007: Periglacial landforms in the Pohorje mountains. Dela 27. Ljubljana.

Novak, M., Skaberne, D. 2009: Zgornji karbon in spodnji perm. Geologija Slovenije. Ljubljana.

Ortega, F. F. 2000: El karst en Cantabria. Enseñanza de las Ciencias de la Tierra 8-1. Oviedo.

Osnovna geološka karta SFRJ 1:100.000, 1972: Tolmač za list Ilirska Bistrica. Beograd.

Pavšič, J., Horvat, A. 2009: Eocen, oligocen in miocen v osrednji in vzhodni Sloveniji. Geologija Slovenije. Ljubljana.

Planina, T. 1954. Kako se je razvila loška pokrajina. Loški razgledi 1. Škofja Loka.

Planina, T. 1955. Jame in drugi kraški pojavi v okolici Škofje Loke. Loški razgledi 2. Škofja Loka.

Ramovš, A., Buser, S. 2009: Devon in spodnji karbon. Geologija Slovenije. Ljubljana.

Skaberne, D., Ramovš, A., Ogorelec, B. 2009: Srednji in zgornji perm. Geologija Slovenije. Ljubljana.

Smart, P. L., Beddows, P.A., Coke, J., Doerr, S., Smith, S., Whitaker, F.F. 2006: Cave development on the Caribbean coast of the Yucatan Peninsula, Quintana Roo, Mexico. Geological Society of America Special Papers 404. DOI: 10.1130/2006.2404(10)

Stepišnik, U., Ferk, M., Gostinčar, P., Černuta, L. 2012: Holocene high floods on Planina Polje, Classical Dinaric Karst, Slovenia. Acta Carsologica 41-1. Ljubljana.

Stepišnik, U., Mihevc, A. 2008: Investigation of structure of various surface karst formations in limestone and dolomite bedrock with application of the electrical resistivity imaging. Acta Carsologica 37-1. Ljubljana.

Šifrer, M. 1952: Obseg poledenitve na Pokljuki. Geografski vestnik 24. Ljubljana.

Šifrer, M. 1961: Porečje Kamniške Bistrice v Pleistocenu. Dela SAZU 12. Ljubljana.

Šifrer, M. 1969: Kvartarni razvoj Dobrav na Gorenjskem. Geografski zbornik 11. Ljubljana. 
Šifrer, M. 1992: Geomorfološki razvoj Blejsko-Radovljiške kotline in Dobrav v kvartarju. Radovljica.

Vacher, H. L., Mylroie J.E. 2002: Eogenetic karst from the perspective of an equivalent porous medium. Carbonates and Evaporites 17-2. Berlin. DOI: 10.1007/BF03176484

Zampieri, D., Ferrarese, F., Sauro, U. 2005: Aspetti della speleogenesi del Montello. In: Castiglioni, B. (Ed.): Montello. Montebelluna: Museo di Storia Naturale e Archeologia. Treviso.

Zhang, C. 2011: Longmen Dong Cave. Private correspondence of the authors.

Zorn, M. 2009: Erosion processes in Slovene Istria - part 2: Badlands. Acta geographica Slovenica, 49-2. Ljubljana. DOI: 10.3986/AGS49203

Žlebnik, L. 1971: Pleistocen Kranjskega, Sorškega in Ljubljanskega polja (Pleistocene Deposits of the Kranj, Sora and Ljubljana Fields). Geologija 14. Ljubljana.

Žlebnik, L. 1978: Kras na konglomeratnih terasah ob Zgornji Savi in njenih pretokih (Karstification of conglomeratic terraces along the Upper Sava River and tributaries). Geologija 21. Ljubljana. 



\title{
Eogenetske jame v pleistocenskem karbonatnem konglomeratu v Sloveniji
}

\author{
DOI: $10.3986 /$ AGS52101 \\ UDK: 911.2:551.44(497.4) \\ COBISS: 1.01
}

IZVLEČEK: V članku so obravnavane jame v pleistocenskem karbonatnem konglomeratu v Sloveniji in prvič opredeljene kot eogenetske jame. Ker konglomerati pleistocenske starosti v Sloveniji niso nikoli šli skozi fazo stiskanja pod visokimi pritiski, kar bi odražalo mezogenetsko fazo diageneze, so zato še vedno $\mathrm{v}$ zgodnji fazi diageneze oziroma v eogenetski fazi. Na podlagi speleoloških analiz smo eogenetske jame razdelili v štiri tipe: (1) linearne epifreatične jame, (2) spodmoli, (3) podorne jame in (4) brezna. Vsi štirje opisani tipi jam se lahko pojavljajo posamezno, vendar so daljši jamski sistemi lahko tudi kombinacija različnih tipov jamskih rovov, ki so se oblikovali $\mathrm{z}$ različnimi procesi v različnih obdobjih.

KLJUČNE BESEDE: geografija, geomorfologija krasa, speleologija, jame v konglomeratu, eogenetske jame, pleistocen, Slovenija

Uredništvo je prejelo prispevek 7. decembra 2011.

NASLOVA:

Mateja Ferk

Geografski inštitut Antona Melika

Znanstvenoraziskovalni center Slovenske akademije znanosti in umetnosti

Gosposka ulica 13, SI - 1000 Ljubljana, Slovenija

E-pošta: mateja.ferk@zrc-sazu.si

\section{Matej Lipar}

Environmental Geoscience

Department of Agricultural Sciences

Faculty of Science, Technology and Engineering

La Trobe University

Victoria 3086, Australia

E-pošta: mlipar@students.latrobe.edu.au

\section{Vsebina}

1 Uvod 27

2 Jame v konglomeratu 27

3 Pleistocenski konglomerati v Sloveniji 27

$4 \quad$ Eogenetske jame 28

$5 \quad$ Eogenetske jame v pleistocenskih

6 Razprava 32

$7 \quad$ Sklep $\quad 32$

8 Zahvala 33

9 Literatura 33 


\section{Uvod}

Jame v konglomeratih so že bile opredeljene in opisane tako v slovenski (Gantar 1955; Žlebnik 1978; Gabrovšek 2005; Kranjc 2005; Lipar in Ferk 2011) kot tudi v svetovni literaturi (Günay 1985; Bergadá in ostali 1997; Filippov 2004; Ferrarese in Sauro 2005; Zampieri in ostali 2005; Lapaire in ostali 2006; Goeppert in ostali 2011), kljub temu pa ostajajo med slabše proučenimi kraškimi oblikami. Dosedanja slovenska literatura, ki je obravnavala jame v konglomeratu, je bila usmerjena zlasti na proučevanje jam v konglomeratni terasi Udin Boršt (Gantar 1955; Gabrovšek 2005; Kranjc 2005; Lipar in Ferk 2011).

Jame v konglomeratu so pogosto označene kot poseben tip kraških jam, vendar lahko znotraj te skupine ločimo številne podskupine. Ker sta nastanek in izoblikovanje jam odvisna od litoloških in tektonskih značilnosti konglomeratov, je za razumevanje speleogeneze $v$ konglomeratih pomembno poznavanje geoloških predispozicij. Tipi jam v pleistocenskih konglomeratih v Sloveniji so na primer precej drugačni od tipov jam v terciarnih ali starejših konglomeratih. Med diagenezo namreč konglomerate preoblikujejo različni procesi (npr. stiskanje pod visokimi pritiski zaradi prekritja s karbonatnimi morskimi sedimenti), zaradi česar postanejo po poroznosti bolj podobni apnencem $v$ telogenetski fazi kot pa konglomeratom $\mathrm{v}$ eogenetski fazi. Zaradi tega so tudi speleogenetski procesi jam v oligocenskih konglomeratih v Sloveniji (npr. Marijini brezno, kat. št. 6) bolj podobni nastanku jam v mezozojskih apnencih (Kataster jam JZS 2011). Zaradi tega moramo nujno razlikovati konglomerate, ki so v različnih diagenetskih fazah.

Pričujoče delo obravnava poglavitne speleogenetske značilnosti jam v konglomeratih v eogenetski fazi diageneze, zato je osredotočeno na jame v pleistocenskih konglomeratih. Na podlagi obsežnega študija literature in terenskega dela smo opredelili temeljne speleološke značilnosti vseh poznanih jam v pleistocenskih konglomeratih v Sloveniji. Poglavitni nameni objave so (1) predstavitev razporeditve jam v pleistocenskih konglomeratih v Sloveniji, (2) opisi njihovih morfoloških in speleogenetskih značilnosti ter (3) predstavitev poglavitnih tipov eogenetskih jam v konglomeratih.

\section{Jame v konglomeratih}

Pojem »jame v konglomeratih « se nanaša na širšo geološko (sedimentološko) pojmovanje in opredeljuje jame, ki so oblikovane v grobo zrnatih $(>2 \mathrm{~mm})$ cementiranih sedimentnih kamninah, imenovanih tudi kalciruditi. Zaradi različne starosti konglomerata, mineraloške sestave sedimentov, poroznosti in tudi metamorfoze je številčnost jamskih tipov velika. Ker je pojem precej širok in splošen, je za podrobnejšo interpretacijo jam nujno nadaljnje razčlenjevanje jamskih tipov.

Jame v eogenetskih konglomeratih miocenske in pleistocenske starosti so poznane iz Italije (Ferrarese in Sauro 2005; Zampieri in ostali 2005), Turčije (Günay 1985; Değirmenci in Günay 1993) in Slovenije (Gantar 1955; Gabrovšek 2005; Kranjc 2005; Lipar in Ferk 2011). Na genezo večine teh jam je pomembno vplivala medzrnska poroznost konglomerata, njegova prepustnost in neotektonska razpokanost, zato so si med seboj zelo podobne. Jame v konglomeratih večje starosti so bile opisane v Rusiji (ordovicijska starost) (Filoppov 2004; Klimchouk 2004), Švici (oligocen) (Lapaire in ostali 2006), Španiji (eocen, oligocen) (Bergadá in ostali 1997; Ortega 2000), na Kitajskem (kreda) (Lynch 2003a in 2003b; Zhang 2011) ter v Avstriji, Nemčiji (oligocen, miocen) (Goeppert in ostali 2011) in Sloveniji (oligocen) (Planina 1954, Planina 1955; Kataster jam JZS 2011). Kljub temu, da večja starost konglomerata sama po sebi še ne izključuje eogenetske faze, se starejše jame razlikujejo od jam v pleistocenskih konglomeratih zaradi različnih značilnosti konglomeratov. Pred primerjanjem ali tipizacijo jam v konglomeratih je zato treba podrobno proučiti značilnosti posameznih konglomeratov.

\section{Pleistocenski konglomerati v Sloveniji}

Najstarejši konglomerati na območju Slovenije so iz devona (Markič 2009; Nova in Skaberne 2009; Pavšič in Horvat 2009; Ramovš in Buser 2009; Skaberne in ostali 2009). Starejši konglomerati, vključno $\mathrm{s}$ konglomerati terciarne starosti, so bili podvrženi različnim procesom diageneze, zato niso več v eogenetski fazi, temveč v mezogenetski ali telogenetski fazi diageneze. Mlajši, kvartarni, konglomerati pa niso bili podvrženi diagenetskim procesom in jih zato obravnavamo kot kamnine v eogenetski fazi diageneze. 
Za kvartar oziroma pleistocen so značilna velika podnebna nihanja med obdobji glacialov in interglacialov. Sedimenti pleistocenske starosti v Sloveniji so vsaj posredno povezani z delovanjem ledenikov, ki so v času njihovega največjega obsega prekrivali večja območja Alp (Melik 1930; Šifrer 1952, Kuščer 1955; Šifrer 1961, Meze 1966; Šifrer 1969 in 1992; Bavec in Verbič 2004), najvišje predele Dinarskega gorovja (Snežnik, Trnovski Gozd) (Osnovna geološka karta SFRJ 1972; Bavec in Pohar 2009), periglacialni pojavi pa so zaznamovali Pohorje (Natek 2007; Gams 2008).

Ostanki ledeniške akumulacije so v glavnem omejeni na alpsko pokrajino, medtem ko je rečno-ledeniška in rečna sedimentacija potekala po vsej Sloveniji. Akumulacije pleistocenskih sedimentov so značilne za Ljubljansko kotlino, porečje srednje in spodnje Savske doline, Soško dolino (Komac in Zorn 2007; Komac 2009), celotno porečje Savinje in za naplavne ravnice ob Dravi in Muri. V obdobju pleistocena je bila akumulacija značilna tudi za dinarska kraška polja (Stepišnik in Mihevc 2008; Bavec in Pohar 2009; Stepišnik in ostali 2012). Z izjemo Drave in Mure v slovenskih porečjih v glavnem prevladuje karbonatno gradivo. Karbonatni konglomerati imajo pretežno kalcitno vezivo. Temeljno razčlenitev kvartarnih sedimentov v Sloveniji je opravil Kuščer (1955), Žlebnik (1971) pa je kvartarne sedimente razdelil na štiri glavna sedimentacijska obdobja. Ločil je starejšo, srednjo in mlajšo konglomeratno zapolnitev ter najmlajšo prodno zapolnitev. V karbonatnih konglomeratih so se oblikovali površinski kraški relief in podzemne kraške oblike, kot so jame. Na podlagi geološke razvojne stopnje oziroma zgodnje diagenetske faze konglomeratov smo jame opredelili kot eogenetske kraške oblike.

\section{Eogenetske jame}

Termin eogeneza sta vpeljala Choquette in Pray (1970) in ga opredelila kot časovni interval med končno sedimentacijo in zasutjem $\mathrm{z}$ mlajšimi sedimenti do globine, kjer na diagenezo začnejo vplivati drugi dejavniki, kot je na primer stiskanje pod visokimi pritiski (Choquette in Pray 1970,219). Pomen izraza se prekriva s terminom »zgodnja diageneza«, ki ga je opredelil Berner (1980). V povezavi z »eogenetsko fazo« sta bila opredeljena še dva druga termina, ki se nanašata na obdobje globoke zasutosti z drugimi sedimenti (»mezogenetska faza«) in obdobje erozije karbonatov, ki so bili dolgo časa pod velikimi pritiski nad njimi odloženih sedimentov (»telogenetska faza») (Choquette in Pray 1970, 219).

Izraz eogeneza se je v kasnejši literaturi uporabljal v besedni zvezi »eogenetski kras« (Vacher in Mylroie 2002; Florea in Vacher 2006; Grimes 2006; Ginés in Ginés 2007) in »eogenetske jame« (Vacher in Mylroie 2002; Grimes 2006; Smart in ostali 2006; Florea in ostali 2007; Ginés in Ginés 2007; De Waele in ostali 2009). Eogenetske jame nastajajo v mehkem, poroznem in slabo cementiranem apnencu, ki je še zmeraj v eogenetski fazi diageneze (Grimes 2006), zato so značilne za obalna območja (Vacher in Mylroie 2002; Grimes 2006; Smart in ostali 2006; Ginés in Ginés 2007), čeprav so bile opisane tudi v celinskih predelih (Florea in ostali 2007; Lipar in Ferk 2011). Kljub temu da se termin »eogenetske jame« najpogosteje uporablja za obalne jame v kvartarnih apnencih, se izraz nanaša na splošni geološki vidik, zaradi česar je pestrost jamskih tipov v tovrstnih kamninah lahko velika. Lipar in Ferkova (2011) sta eogenetske jame v konglomeratih na podlagi jam v konglomeratni terasi Udin Boršt v zahodni Sloveniji razdelila v štiri osnovne tipe.

\section{Eogenetske jame v pleistocenskih konglomeratih v Sloveniji}

V Sloveniji poznamo vsaj šestintrideset jam v pleistocenskih konglomeratih, ki so tudi registrirane v Katastru jam Jamarske zveze Slovenije (Kataster jam IZRK 2011; Kataster jam JZS 2011) (Slika 1). Točnega števila jam ni možno določiti zaradi novo odkritih jam, ki so še v procesu registracije, in zaradi nekaterih nedostopnih in/ali uničenih jam. V Ljubljanski kotlini, kjer so registrirane edine slovenske eogenetske jame v konglomeratih, so le-te večinoma oblikovane na robovih konglomeratnih teras ali rečnih dolin. Približno $40 \%$ jam je na območju pleistocenske konglomeratne terase Udin Boršt, ostale pa so povečini na terasah in stenah kanjonov Save in Kokre (Slika 1).

Slika 1: Lega eogenetskih jam v pleistocenskem konglomeratu v Sloveniji.

Glej angleški del prispevka. 
Acta geographica Slovenica, 52-1, 2012

Preglednica 1: Osnovni podatki o eogenetskih jamah v pleistocenskih karbonatnih konglomeratih v Sloveniji.

\begin{tabular}{|c|c|c|c|c|c|c|}
\hline $\begin{array}{l}\text { katastrska } \\
\text { številka }\end{array}$ & ime & $\begin{array}{l}\text { dolžina } \\
\text { (m) }\end{array}$ & $\begin{array}{c}\text { globina } \\
\text { (m) }\end{array}$ & $\begin{array}{c}\text { kota } \\
\text { vhoda }(m)\end{array}$ & $\begin{array}{l}\text { katastrska } \\
\text { občina }\end{array}$ & tip* \\
\hline 367 & Jama pri taboru & 110 & 7 & 460 & Cešnjica pri Kropi & linearna epifreatična jama \\
\hline 397 & Jama pri Lipniški skali & 31 & 6 & 465 & Dobrava pri Kropi & spodmol \\
\hline 763 & Arneževa luknja & 815 & 13 & 470 & Duplje & linearna epifreatična jama \\
\hline 764 & Dopulnik & 306 & 6 & 466 & Duplje & linearna epifreatična jama \\
\hline 765 & Velika Lebinca & 200 & 13 & 421 & Strahinj & linearna epifreatična jama \\
\hline 766 & Mala Lebinca & 6 & 1 & 440 & Strahinj & spodmol \\
\hline 1075 & Dacarjevo brezno & 307 & 19 & 590 & Duplje & linearna epifreatična jama \\
\hline 1076 & Brezno v Kvikšovem partu & 3 & 3 & 520 & Duplje & brezno \\
\hline 1077 & Jama v Arhovem partu & 13 & 5 & 520 & Duplje & brezno \\
\hline 1078 & Arhova jama & 25 & 3 & 465 & Duplje & linearna epifreatična jama \\
\hline 1081 & Arneševa zijalka & 19 & 4 & 460 & Duplje & linearna epifreatična jama \\
\hline 1233 & Jama pri Dobravi & $?$ & $?$ & 420 & Zaloše & nedoločeno \\
\hline 1315 & Jama pod Stolcem nad Zalošami & 11 & 2 & 450 & Zaloše & spodmol \\
\hline 1339 & Šmajdov grad & 8 & 3 & 390 & Predoslje & spodmol \\
\hline 1340 & Urhov kevder & 8 & 0 & 350 & Jama & spodmol \\
\hline 1341 & Janharjeva jama & 5 & 0 & 334 & Podreca & spodmol \\
\hline 2404 & Ciganska jama & 10 & 2 & 445 & Podbrezje & spodmol \\
\hline 2746 & Projev grez & 9 & 8 & 361 & Godešic & brezno \\
\hline 2878 & Partizanska jama pod Okroglim & 15 & 3 & 430 & Okroglo & spodmol \\
\hline 3074 & Jama na Studencu & 10 & 0 & 274 & Slape & spodmol \\
\hline 4171 & Kadunčev studenec & 20 & 6 & 440 & Strahinje & linearna epifreatična jama \\
\hline 4172 & Kamponov kevder & 10 & 0 & 340 & Breg ob Savi & spodmol \\
\hline 4381 & Arhova zijalka & 10 & 1 & 470 & Duplje & spodmol \\
\hline 4580 & Spodmol 1 pod Dragočajno & 8 & 0 & 337 & Moše & spodmol \\
\hline 4581 & Spodmol 2 pod Dragočajno & 6 & 3 & 337 & Moše & spodmol \\
\hline 4582 & Spodmol 3 pod Dragočajno & 8 & 0 & 341 & Moše & linearna epifreatična jama \\
\hline 4583 & Turška jama & 20 & 1 & 342 & Podreca & spodmol \\
\hline 4599 & Pekel v Klemenčevem gradišču & 17 & 6 & 462 & Gorice & linearna epifreatična jama \\
\hline 4639 & P-2 (Brezovica) & 21 & 9 & 480 & Cešnjica pri Kropi & linearna epifreatična jama \\
\hline 4648 & Vočanarjeva luknja & 19 & 5 & 407 & Predoslje & nedoločeno \\
\hline 4694 & Rokovnjača & 10 & 1 & 485 & Duplje & linearna epifreatična jama \\
\hline 6950 & Kačja jama nad Spodnjimi Dupljami & 13 & 6 & 470 & Duplje & podorna jama \\
\hline 8442 & Jama pod Žalami & 65 & 3 & 390 & Kamnik & linearna epifreatična jama \\
\hline 9874 & Konglomeratovka & 14 & 3 & 493 & Hraše & spodmol \\
\hline 10025 & Vojvodov kevder & 10 & 2 & 472 & Gorice & linearna epifreatična jama \\
\hline \multicolumn{7}{|l|}{ (v procesu } \\
\hline registracije) & Kinderjajček & 25 & 3 & 445 & Strahinj & linearna epifreatična jama \\
\hline
\end{tabular}

* Naveden je prevladujoč tip nastanka jamskih rovov.

Najdaljša jama v pleistocenskih konglomeratih v Sloveniji je Velika Lebinca (kat. št. 765). Nastala je v konglomeratni terasi Udin Boršt in ima 1154 metrov izmerjenih rovov. Druga najdaljša jama je Arneževa luknja (kat. št. 763), ki je prav tako v Udin Borštu in ima 815 metrov izmerjenih rovov. Će izvzamemo jame v Udin Borštu, je najdaljša Jama pri taboru s 110 metri izmerjenih rovov (kat. št. 367). Nastala je v okolici Podnarta, južno od naselja Rovte.

Kakor sta že Lipar in Ferkova (2011) določila za eogenetske jame v Udin Borštu, je tudi eogenetske jame v pleistocenskih konglomeratih v Sloveniji možno razdeliti v štiri različne tipe eogenetskih jam: (1) linearne epifreatične jame, (2) spodmole, (3) podorne jame in (4) brezna.

Veliko eogenetskih jam smo lahko opredelili kot linearne epifreatične jame (slike 2, 3 in 8 ). V hidrološkem smislu te jame delujejo kot stalni ali občasni izviri. Nobena jama tega tipa ni nastala kot ponor voda, ki bi odtekale v kras. Vhodni deli jam tega tipa so običajno večji (višji od $1 \mathrm{~m}$ in več metrov široki; običajno preoblikovani kot spodmoli) kot notranji deli vodoravnih jamskih rovov, ki se z oddaljenostjo od vhoda čedalje bolj zožujejo in nižajo. Vodoravni jamski rovi so prvotno nastali na piezometričnem nivoju. Ker se je v preteklosti piezometrični nivo spreminjal, so v nekaterih jamah višje etaže vodoravnih jamskih rovov, ki jih današnji piezometrični nivo ne doseže več. Primera sta Arneževa luknja (kat. št. 763) in Jama 
pri taboru (kat. št. 367). Zaradi relativnega znižanja piezometričnega nivoja, se je vodni tok iz nekaterih jam povsem umaknil, zato so lahko jame, ki genetsko pripadajo linearno epifreatičnemu tipu eogenetskih jam, $v$ recentnih hidroloških razmerah povsem hidrološko neaktivne in ležijo v vadozni hidrografski coni krasa (Spodmol 3 pod Dragočajno, kat. št. 4582). Jame tega tipa imajo običajno en glavni pretočni kanal in zgolj posamezne kratke stranske rove, po katerih dotekajo pritoki v glavni vodni tok. Speleogeneza glavnih pretočnih kanalov je bila v največji meri podvržena vplivom razpoklinske poroznosti (razpoke, prelomi), ki jo opisujejo tudi Bergadá in ostali (1997), Lapaire in ostali (2006) ter Değirmenci in Günay (1993). Sekundarne prečne razpoke so običajno povzročile oblikovanje kratkih stranskih rovov. Vpliv razpok na oblikovanje jam je možno opazovati v ozkih in visokih rovih, kjer so na jamskih stropih povečini dobro vidni prelomi ali v pravilnih linijah oblikovani stalaktiti. Njihova linijska razporeditev kaže na to, da so rasli iz vode, ki je pritekala po glavni razpoki (Dopulnek, kat. št. 764) ali po stranskih razpokah (Arneževa luknja, kat. št. 763) (slika 2).

Ponekod so jamski rovi nizki in široki (Jama pri taboru, kat. št. 367), kar odseva vpliv medzrnske poroznosti in drugih značilnosti konglomeratnega gradiva (slika 3). V takšnih delih jamskih rovov na stropu ni vidnih sledi prelomov ali razpok, stalaktiti pa so poljubno razporejeni po jamskem stropu. Če med seboj primerjamo samo rove, ki so nastali pod vplivom medzrnske poroznosti, pa lahko ugotovimo, da so rovi, oblikovani v konglomeratu iz večjih prodnikov (s premeri od 1 do $10 \mathrm{~cm}$ ), ožji od rovov, oblikovanih v drobnozrnatem gradivu konglomerata (s premeri prodnikov, manjšimi od $1 \mathrm{~cm}$, in prevlado peščenih zrn). Sklepamo, da so plasti drobnozrnatih sedimentov v konglomeratu slabše odporne na vodno erozijo kot plasti konglomerata iz večjih prodnikov. Podobne značilnosti jamskih rovov so opisovali tudi Zampieri in ostali (2005). V posameznih delih linearnih epifreatičnih jam, so tudi podori jamskih stropov, ki so oblikovali razširitve oziroma manjše podorne dvorane (Arneževa luknja, kat. št. 763).

Slika 2: Primeri eogenetskih jam linearnega epifreatičnega tipa (A, B - Arneževa luknja; C - Dopulnek; D - Kinderjajček).

Glej angleški del prispevka.

Slika 3: Jamski rovi, oblikovani pod vplivom matrične poroznosti (A - Arneževa luknja; B - Jama pri taboru) Glej angleški del prispevka.

Poleg linearnih epifreatičnih jam so $\mathrm{v}$ pleistocenskih konglomeratih zelo pogost tip eogenetskih jam tudi spodmoli (slike 4, 5 in 6). Najpogostejši so na pobočjih konglomeratnih teras (Arhova zijalka, kat. št. 4381) ali na strmih pobočij dolin in kanjonov (Spodmol 1 pod Dragočajno, kat. št. 4580). Ne glede na njihovo preprosto morfološko podobo so na njihov nastanek vplivali različni dejavniki. Ford in Williams (2007) sta nastanek spodmolov pojasnila kot rezultat zmrzalnega preperevanja in jih imenujeta tudi »zmrzalni žepi« (ang. frost pockets). Spodmoli običajno nastanejo v trdnih karbonatnih kamninah, kjer se razpoke vlažijo po korozijsko razširjenih odprtinah. Korozija vode, ki izteka iz razpok, je ključni proces za širjenje odprtin, zmrzalno preperevanje pa jih samo še širi (Ford in Williams 2007; prim. Zorn 2009).

Spodmoli v pleistocenskih konglomeratih so rezultat razpršenega napajanja izvirov po medzrnskih porah brez vidnih razpok v konglomeratu in zmrzalnega preperevanja, ki različno intenzivno deluje na posamezne plasti konglomerata, oboje pa pomembno vpliva na nadaljnje oblikovanje spodmolov. Zmrzalno preperevanje dokazujejo odlomljeni kosi konglomerata različnih dimenzij (od peska do podornih blokov), ki ležijo na dnu spodmolov. Kadar se spodmol nadaljuje v linearno epifreatično jamo, smo jamo opredelili kot linearno epifreatično jamo z vhodom v obliki spodmola (Jama pri Lipnici, kat. št. 397). Velikost spodmolov variira od 1 do $10 \mathrm{~m}$ v širino in od 0,5 do $6 \mathrm{~m}$ ter več v višino. Spodmoli so običajno dolgi do $10 \mathrm{~m}$, pogosto pa so bolj široki kot dolgi (Spodmol 2 pod Dragočajno, kat. št. 4581) (Slika 6).

Ker so bile nekatere jame $\mathrm{v}$ pleistocenskih konglomeratih registrirane še pred uvedbo pravila o minimalni dolžini jam za registracijo $(10 \mathrm{~m})$, so kot jamski objekti registrirani tudi nekateri spodmoli, krajši od $10 \mathrm{~m}$ (Janharjeva jama, kat. št. 1341). V konglomeratu je zato veliko spodmolov, krajših od $10 \mathrm{~m}$, ki niso vpisani v register kraških jam Katastra jam Jamarske zveze Slovenije. Spodmoli so običajno povsem suhi in hidrološko neaktivni. Čeprav v nekaterih primerih delujejo tudi kot izviri, voda najpogosteje izvira v občasnih izvirih nekaj metrov pod spodmoli. Kjer v konglomeratu ni inicialnih razpok, ki bi združevale pronicujočo vodo v izdatnejši tok, je nastalo več manjših spodmolov na isti nadmorski višini, ki kaže na trenutni ali nekdanji piezometrični nivo. Piezometrični nivo je pogojen s splošnimi hidrološkimi razmerami okolice in z ravnijo stika med prepustnimi konglomerati ter neprepustnimi kamninami pod njimi (oligocenska sivica). Prelomi 
so na takšnih mestih redki. Običajno so mlajši prelomi ob robovih teras, ki so nastali zaradi nestabilnosti konglomeratnih sten. Siga se v takšnih legah praviloma ne izloča. Prvotna oblika spodmolov je pogosto antropogeno spremenjena, saj so jih v preteklosti okoliški prebivalci uporabljali za zaklonišča in lope: vhod v Šmajdov grad (kat. št. 1339) je bil povsem preoblikovan z izgradnjo varovalnega zidu, Turška jama (kat. št. 4583) je bila preoblikovana za obrambo okoliških prebivalcev pred Turki v 16. stoletju; Urhov kevder (kat. št. 1340) in Arhova zijalka (kat. št. 4381) pa sta služila za shranjevanje orodja s sosednjih kmetij) (Slika 5).

Slika 4: Primeri spodmolov (A - Ciganska jama; B - majhni spodmoli v kanjonu Kokre; C - Spodmol 1 pod Dragočajno; D - Urhov kevder). Glej angleški del prispevka.

Slika 5: Antropogeno preoblikovani spodmoli (A - Turška jama; B - Šmajdov grad; C - Partizanska jama pod Okroglim; D - Dacarjevo brezno). Glej angleški del prispevka.

Slika 6: Načrt jame Spodmol 2 pod Dragočajno.

Glej angleški del prispevka.

Jame v pleistocenskih konglomeratih, ki so jih podori preoblikovali v tolikšni meri, da primarni korozijski rovi niso več dostopni, uvrščamo med podorne jame (slika $7 \mathrm{~B}$ in $\mathrm{C}$ ). Podori nastajajo v slabo cementiranem konglomeratu, kjer je kamnina zdrobljena ob prelomih ali razširitvah nad predhodno korozijsko izoblikovanimi rovi. Podorni rovi so na relativno višji nadmorski višini od primarnih jamskih rovov, zato v njih ni aktivnih vodnih tokov. Podorne jame niso nujno v celoti oblikovane v podorih, saj so v nekaterih primerih med podornimi bloki še dostopni nižje ležeči hidrološko aktivni rovi (Kadunčev studenec, kat. št. 4171) (slika 8). V takšnih primerih smo jame na podlagi primarne geneze uvrstili v linearni epifreatični tip eogenetskih jam in ne med podorne jame. Lokalni podori, ki so omejeni na krajše odseke jam drugega tipa eogenetskih jam, namreč niso ustrezen dejavnik za določanje podornega tipa jam. Osnovna razlika med lokalnim podorom $\mathrm{v}$ jami in podornim tipom jame je $\mathrm{v}$ tem, da so lokalni podori sekundarni proces $v$ jamah drugega tipa, kjer tekoča voda še ni odstranila podornih blokov, ki so se odkrušili z jamskega stropa, in so deformacija $\mathrm{v}$ delu jame, $\mathrm{v}$ kateri sicer prevladujejo drugi procesi. Podori v podornem tipu jam pa so najpomembnejši morfološki proces, ki je v celoti preoblikoval prvotni jamski rov in oblikoval »nov« podzemni prehod na relativno višji nadmorski višini od prvotnega jamskega rova.

Slika 7: Primeri podorov (A - Vočanarjeva luknja; B - Arneževa luknja; C - Kačja jama nad Spodnjimi Dupljami).

Glej angleški del prispevka.

Slika 8: Načrt jame Kadunčev Studenec.

Glej angleški del prispevka.

Četrti tip eogenetskih jam v pleistocenskih konglomeratih so brezna. Pojavljajo se redko in so pogosto premalo globoka (manj kot $10 \mathrm{~m}$ ) za registracijo v Katastru jam Jamarske zveze Slovenije. Jame, ki se uvrščajo v ta tip eogenetskih jam, so najpogostejše na območju konglomeratne terase Udin Boršt. Brezna in vertikalni vhodi v jame drugih tipov, z izjemo vhoda v Kačjo jamo nad Spodnjimi Dupljami (kat. št. 6950), so bila antropogeno uničena - zasuta $\mathrm{z}$ odpadki ali drugim gradivom (Dacarjevo brezno, kat. št. 1075; Jama v Arhovem partu, kat. št. 1077; Projev grez, kat. št. 2746). V osrednjem delu konglomeratne terase Udin Boršt je več navpičnih odprtin, ki ne dosegajo minimalne dolžine za registracijo jam. Brezna se lahko pojavljajo individualno kot vertikalne odprtine brez nadaljevanja v druge podzemne odprtine ali kot vhodi $\mathrm{v}$ jame drugih tipov eogenetskih jam. V slednjem primeru brezna in nižje ležeče jame niso nujno genetsko povezani. Brezna se namreč oblikujejo v vadozni hidrografski coni s koncentriranim odtokom padavinske vode v podzemlje, po čemer se razlikujejo od prej opisanih tipov eogenetskih jam.

Posebna jama v pleistocenskih konglomeratih je Vočanarjeva luknja (kat. št. 4648) (slika 7 A). Je odprtina med podorni bloki, ki so se odlomili od stene kanjona. Ker je oblikovanje tovrstnih odprtin oziroma jam naključno, brez genetske povezave s korozijo ali eogenetsko fazo diageneze konglomerata, jama ne more biti uvrščena $\mathrm{v}$ noben opisan tip eogenetskih jam v pleistocenskem konglomeratu v Sloveniji, na podlagi nastanka te jame pa tudi ne more biti opredeljen dodaten, poseben tip eogenetskih jam. 


\section{Razprava}

V prispevku so opisani štirje tipi eogenetskih jam v konglomeratih pleistocenske starosti. Kljub širokemu pomenu izraza »eogeneza«, sva se avtorja oprla nanj, saj ga je obravnavala številna literatura: Smart in ostali 2006; Florea in ostali 2007; Ginés in Ginés 2007; De Waele in ostali 2009; Lipar in Ferkova 2011. Kadar opredeljujeva eogenetske jame, misliva na skupno značilnost kamnine, ki je delno vplivala na vsesplošno genezo jam, to je primarno medzrnsko poroznost (»primarna poroznost« v Choquett in Pray (1970); »medzrnska poroznost « v Ford in Williams (2007); »medzrnska in spužvasta (vuggy) poroznost« v Lucia (2007). V kasnejšem obdobju zgodnje diageneze, vendar še zmeraj v eogenetski fazi, se lahko primarna poroznost delno preoblikuje zaradi zmanjšane prepustnosti, vendar ostane tip poroznosti enak. Lahko se pojavi tudi nova oblika poroznosti (»sekundarna poroznost« v Ford in Williams 2007) kot na primer razpoklinska poroznost.

V pleistocenskih karbonatnih konglomeratih v Sloveniji je še zmeraj prisotna primarna medzrnska poroznost. Pleistocenski konglomerati so sicer bolj ali manj cementirani in zakraseli, zato je primarna poroznost delno spremenjena do različnih stopenj. Medzrnska poroznost je najbolj vidna v spodmolih, kamor voda priteka razpršeno med zrni konglomerata, in v nekaterih delih linearnih epifreatičnih jam, kjer so nastali nizki in široki jamski rovi. V pleistocenskih konglomeratih se pojavlja tudi sekundarna (razpoklinska) poroznost, ki je vplivala na nastanek nekaterih jam. Vidna je v večini linearnih epifreatičnih jam, ki imajo glavne jamske rove oblikovane in usmerjene ob prelomih. Glede na to, da Ford in Williams (2007) opredeljujeta korozijske jame kot terciarno poroznost, ugotavljamo, da se v pleistocenskih karbonatnih konglomeratih v Sloveniji pojavljajo primarna, sekundarna in terciarna poroznost. Jame v konglomeratih, ki so v eogenetski fazi diageneze, moramo razlikovati od jam v konglomeratih, ki so v mezogenetski ali telogenetski fazi diageneze (Filippov 2004; Klimchouk 2004; Goeppert in ostali 2011). Prav tako jih moramo razlikovati od jam v drugačnih eogenetskih kamninah (Jennings 1968; Grimes 2006; De Waele in ostali 2009).

\section{Sklep}

Na ozemlju današnje Slovenije se je v vsej geološki zgodovini usedal prod in se kasneje cementiral v konglomerat. Z izjemo najmlajših konglomeratov kvartarne starosti so bili konglomerati izpostavljeni intenzivni diagenezi, medtem ko so bili prekriti z drugimi sedimenti ali tektonsko dvignjeni. Zaradi tega niso več v eogenetski, ampak v mezogenetski ali telogenetski fazi diageneze. Največje količine pleistocenskih konglomeratov so v Ljubljanski kotlini in v večjih porečjih: Save, Soče, Savinje, Drave in Mure. Ti konglomerati v diagenezi niso nikoli bili izpostavljeni visokim pritiskom, zato so ne glede na starost še zmeraj v eogenetski fazi diageneze. V karbonatnih konglomeratih, ki jih povečini sestavljajo apnenčevi in dolomitni prodniki, so nastale površinske kraške oblike in podzemne jame. Ker so to edina območja v Sloveniji, kjer so razvite eogenetske kraške oblike, le-te predstavljajo pomembno geomorfološko dediščino (Erhartič 2010).

$\mathrm{V}$ članku podrobno obravnavamo eogenetske jame v pleistocenskem karbonatnem konglomeratu v Sloveniji. Na podlagi obsežnih speleoloških morfoloških in morfometričnih analiz razlikujemo štiri tipe eogenetskih jam v pleistocenskem konglomeratu v Sloveniji: (1) linearne epifreatične jame, (2) spodmoli, (3) podorne jame in (4) brezna.

Linearne epifreatične jame so nastale na piezometričnem nivoju v epifreatični hidrografski coni. Nanje so pomembno vplivali razpoke in prelomi (razpoklinska poroznost) ter značilnosti konglomeratnega gradiva (medzrnska poroznost). Tudi spodmoli so nastali tik nad piezometričnim nivojem v epifreatični coni in so delovali ali še delujejo kot izviri. Spodmoli so bili ob speleogenezi močno podvrženi medzrnski poroznosti in zmrzalnemu preperevanju. Nekatere jame ali jamske rove so v celoti preoblikovali procesi krušenja in odlamljanja kamninskih blokov z jamskih stropov in sten, zato smo tovrstne jame opredelili kot podorne jame. Kot v drugih tipih kraških kamnin (na primer v apnencih in drugih karbonatih v telogenetski fazi diageneze) so na območjih koncentriranega odtoka padavinske vode v podzemlje nastala navpična brezna v vadozni hidrografski coni, ki so četrti tip eogenetskih jam v pleistocenskih konglomeratih. Pojavljajo se lahko samostojno ali pa predstavljajo vhode $\mathrm{v}$ jame, ki so nastale $\mathrm{z}$ drugačnimi procesi (linearne epifreatične jame, podorne jame).

Vsi štirje tipi eogenetskih jam se lahko pojavljajo samostojno, vendar so daljši jamski sistemi pogosto kombinacija jamskih rovov, ki so nastali z različnimi procesi, oziroma kombinacija različnih tipov jamskih rovov (npr. Arneževa luknja, kar. št. 763; Kačja jama nad Spodnjimi Dupljami, kat. št. 6950). 


\section{Zahvala}

Avtorja se zahvaljujeva Johnu A. Webbu in Blažu Komacu za konstruktivne komentarje ter anonimnima recenzentoma. Raziskava je bila opravljena v obdobju, ko je soavtor Matej Lipar prejemal štipendijo za podiplomski študij na univerzi La Trobe v Melbournu v Avstraliji.

\section{Literatura}

Glej angleški del prispevka. 